\title{
SIMULATION OF HETERO-JUNCTION SILICON SOLAR CELLS
}

\author{
D. Bjelopavlić ${ }^{1}$, Danijela Pantic ${ }^{2}$, B. Đorđević ${ }^{3}$, D. Pantic ${ }^{1, *}$ \\ ${ }^{1}$ University of Niš, Faculty of Electronic Engineering, Niš, Serbia \\ ${ }^{2}$ ETŠ "Nikola Tesla", Niš, Serbia \\ ${ }^{3}$ Megatrend University, Belgrade, Serbia
}

\begin{abstract}
Solar modules based on single crystal and polycrystalline silicon have almost a $90 \%$ share of the total world market, primarily because of their stable, robust and reliable characteristics. For these reasons, a great deal of attention is devoted to improving their characteristics and especially their efficiency. One of the many approaches includes HIT solar cells (hetero-junction solar cell with an intrinsic thin amorphous layer) fabricated at temperatures below $300^{\circ} \mathrm{C}$. In this paper, the electrical characteristics of HIT solar cells are simulated by using the TCAD Silvaco software package. The structure of HIT solar cell is optimized in order to obtain their maximum efficiency. In addition, the modifications of the simulation procedure, which allow the simulation of HIT solar cell, are described.
\end{abstract}

Keywords: solar cells, hetero-junction, amorphous/crystalline silicon, simulation.

\section{INTRODUCTION}

Mono-crystalline, poly-crystalline and amorphous-crystalline silicon solar cells are the most widely used group of commercial solar cells. This is primarily due to the fact that these solar cells have stable characteristics over a long period of time, good reliability during operation, and their mass production, as developed in the microelectronics technology, allows fast and relatively cheap production of solar cells based on silicon. The declining trend in the price of solar cells continues, and the technology improves so that the efficiency of solar cells produced becomes greater. One of the improvements is a combination of technologies based on single crystalline silicon (mono-crystalline silicon) layer with the addition of a thin amorphous layer. The resulting structure is known as HIT solar cell (hetero-junction with an amorphous intrinsic thin layer) produced by Sanyo Ltd., with the efficiency of commercially produced HIT solar cells over $20 \%$, and with plenty of room for its improvement [1,2].

The production technologies of HIT solar cells use a thin intrinsic amorphous silicon layer (a$\mathrm{Si}: \mathrm{H}(\mathrm{i}))$ which is formed on both sides of wafer (Czochralski n-type c-Si), using low temperature PECVD process that takes place at $175^{\circ} \mathrm{C}$ or $250^{\circ} \mathrm{C}$ [3].In this way they avoid high temperature processes that degrade the interface surface of amorphous film and crystalline bulk. The HIT structure obtained in such a way has multiple advantages over the standard process. First, the width of a band gap Eg of amorphous silicon is in the range of $1.55 \mathrm{eV}$ to

\footnotetext{
${ }^{*}$ Corresponding author: dragan.pantic@elfak.ni.ac.rs
}

$1.87 \mathrm{eV}$, which increases the efficiency at lower wavelengths, where the most concentrated intensity of terrestrial solar radiation can be found. Now, HIT structure shows better temperature characteristics, as well as a higher voltage $\mathrm{V}_{\mathrm{OC}}$ (open-circuit voltage), because of a significant decrease in surface and interface recombination.

This paper presents the simulation results for the technology parameters and electrical characteristics of HIT solar cells. Program ATHENA [4] is used for the simulation of technological processes, while the electrical characteristics are simulated by program ATLAS [5]. ATHENA and ATLAS programs are an integral part of the Silvaco TCAD (Technology Computer-Aided Design) software package. At first, special attention was paid to the definition and analysis of the impact of interfacial and volume states on the characteristics of HIT solar cells, and then the structures of the HIT cells were electrically optimized, primarily in the $V_{o c}$ and output power, taking into consideration the influence of thickness a-Si:H(p+) and the level of doping crystalline silicon substrate.

\section{STRUCTURE OF HIT SOLAR CELL}

The cross-section structure of HIT solar cell with a-Si:H(i) layer between the $\mathrm{p}+$ doped amorphous silicon and $\mathrm{c}-\mathrm{Si}(\mathrm{n}+)$ from the front, and $\mathrm{n}+$ doped amorphous silicon cathode and $\mathrm{c}-\mathrm{Si}(\mathrm{n}+)$ on the back side of solar cells is shown in Figure 1 [6]. The TCO (transparent conductive oxide) is placed on the front 
side (but it could be on both sides to provide a low serial resistance of cathode contact). An aluminum grid is placed on the upper surface, the first electrode, and the bottom surface is aluminum metallization as a second electrode. However, the standard HIT solar cells (Fig. 1b) do not have a-Si:H(i) which reduces the thickness of a-Si:H, but this layer increases the quantum efficiency of the structure, especially in smaller wave lengths, without significant impact on the value of voltage $\mathrm{V}_{\mathrm{oc}}$. The distribution of Impurity profile in the whole structure of HIT solar cell was obtained after simulation of the technology flow in ATHENA.

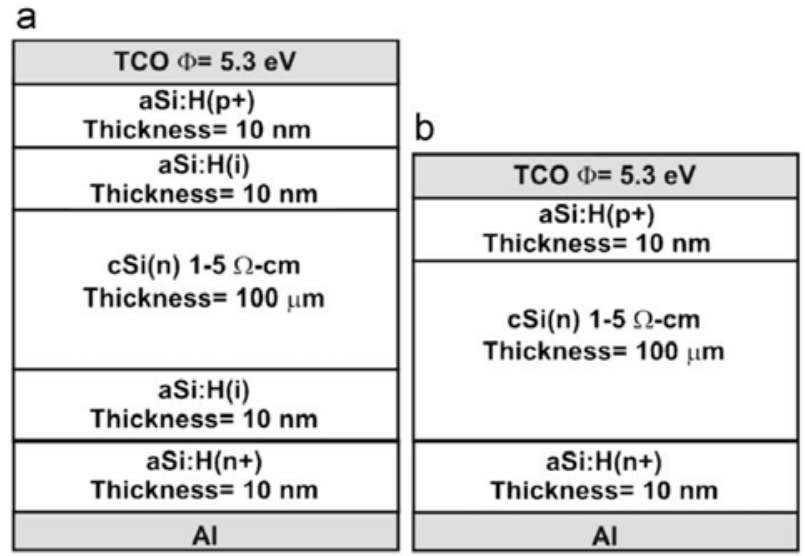

Figure 1. HIT solar cell structure: a) with the a-Si:H(i) layer and b) without this layer [6].

\section{MODELS OF PHYSICAL PARAMETERS}

To be able to simulate the electrical characteristics of HIT solar cells correctly and accurately, it is necessary to properly select and define the parameters of the physical models. This primarily refers to the definition of contacts, and to a model of the carriers generation and recombination, both in amorphous and mono-crystalline silicon, and the interfaces that exist in the structure.

In defining the anode contact (upper), it is necessary to carefully choose the material with its workfunction (WF), which needs to be higher than $5 \mathrm{eV}$. Another parameter that significantly affects the characteristics is the level of doping c-Si. Lower resistance, that is, higher doping $\left(>1 \mathrm{E} 15 \mathrm{~cm}^{-3}\right)$ increases the value of $V_{O C}$, until serial resistance $R_{s}$ is activated, not only due to the presence of interface states (the electronic equivalent is a parallel resistance $R_{p}$ ), but also due to a width decrease of the depletion region, which reduces the absorption "surface" (the depletion region length).

An equivalent model is described in expression (1), where $I$ and $U$ are the output current and the output voltage of solar cells, respectively.
$I=\frac{U}{R_{P}}+I_{0}\left(e^{\frac{q\left(U+I R_{s}\right)}{n K T}}-1\right)-I_{S C}$

The influence of WF on the performance operates over Schottky-contact on the anode, i.e. contact potential, expression (2). This allows defining a barrier height at the metal-semiconductor interface $\varphi_{\mathrm{B}}$, the expression (3).

$\Psi_{S}=\chi+\frac{E_{g}}{2 q}+\frac{k T_{L}}{2 q} \ln \left(\frac{N_{C}}{N_{V}}\right)-W F+U$

$W F=\chi+\phi_{B}$

where $\chi$ is the electron affinity (for amorphous $\mathrm{Si}$ is $3.8 \mathrm{eV}), \mathrm{T}_{\mathrm{L}}$ is the crystal lattice temperature, $\mathrm{T}_{\mathrm{L}}=300 \mathrm{~K}, \mathrm{~N}_{\mathrm{C}}$ is the conduction band density of states of the amorphous $\mathrm{Si}\left(\mathrm{N}_{\mathrm{C}}(300 \mathrm{~K})=2.5 \mathrm{E}+20 \mathrm{~cm}^{-3}\right)$, $\mathrm{N}_{V}$ is the valence band density of states of the amorphous $\mathrm{Si}\left(\mathrm{N}_{\mathrm{V}}(300 \mathrm{~K})=2.5 \mathrm{E}+20 \mathrm{~cm}^{-3}\right)$, the width of bandgap of amorphous silicon is $\mathrm{Eg}=1.72 \mathrm{eV}$; WF and $\chi$ are given as a potential, while $U$ is the voltage on the solar cell.

In defining a model of mobility in silicon, the already adopted values of Klaassen's mobility model are taken, while the value of amorphous silicon electron mobility is $\mu_{\mathrm{e}}=10 \mathrm{~cm}^{2} \mathrm{~V}^{-1} \mathrm{~s}^{-1}$ and the holes mobility $\mu_{\mathrm{h}}=2 \mathrm{~cm}^{2} \mathrm{~V}^{-1} \mathrm{~s}^{-1}$ (in $\mathrm{n}+$ and $\mathrm{p}+\mathrm{a}-\mathrm{Si}: \mathrm{H}$ layers the same values are taken).

The recombination centers have a dominant influence on amorphous-crystalline silicon for which the model must include, in addition to the standard $\mathrm{SRH}$, Auger's model and modified model of surface recombination, where it is necessary to define the acceptor-like states and donor-like states, both at the interface area $\mathrm{a}-\mathrm{Si} / \mathrm{c}-\mathrm{Si}$, and at the grain boundaries, the expression (4). In surface conditions, average carriers' lifetime $\tau_{\mathrm{n}}$ and $\tau_{\mathrm{p}}$ are taken into account, as a function of defect energy states, in the bandgap, and interface charge:

$$
R_{S R H}=\frac{p n-n_{i e}^{2}}{\tau_{p}^{e f f}\left[n+n_{i e} \exp \left(\frac{E-E_{i}}{k T_{L}}\right)\right]+\tau_{n}^{e f f}\left[p+n_{i e} \exp \left(-\frac{E-E_{i}}{k T_{L}}\right)\right]}
$$

The simulation of HIT structure using Silvaco TCAD software package requires defining the defects, as in a-Si: $\mathrm{H}$ and $\mathrm{c}-\mathrm{Si}$ regions, and on the surface a-Si/c-Si. Gap-defect states distribution (or DOS - density of trap states) in a semiconductor is a parameter which models defects in recombination equations. Due to the nature of amorphous-crystalline silicon their density was significantly increased in comparison to structures produced by standard technology. It is understood that the donor-like NTD and acceptor-like NTA states are presented. Howe- 
ver, the profile of energy distribution can be taken as a standard "U" profile by defining the two functions for acceptor and donor cover centers, respectively: exponential "tail" function (Urbach's position) by the end of the zone, and the Gaussian function in the middle of the zone (Gaussian mid-gap states associated to silicon dangling bonds). The total density of states, shown in Figure 2, would then be:

$$
g(E)=g_{T A}(E)+g_{T D}(E)+g_{G A}(E)+g_{G D}(E)
$$

Exponential band "tail" defined for acceptor-like states and donor-like states are:

$$
\begin{aligned}
& g_{T A}(E)=N T A \exp \left(\frac{E-E_{C}}{W T A}\right) \\
& g_{T D}(E)=N T D \exp \left(\frac{E_{V}-E}{W T D}\right)
\end{aligned}
$$

NTA and NTD are the maximum of acceptor-like and donor-like trap densities (band tail density of states), respectively. They are equal in their values $\left(\mathrm{NTA}=\mathrm{NTD}=2 \mathrm{E}+21 \mathrm{~cm}^{-3} \mathrm{eV}^{-1}\right) . \mathrm{E}_{\mathrm{C}}$ is the conduction band energy, $\mathrm{E}_{\mathrm{V}}$ is the valence band energy, WTA and WTD are characteristic decay energy for acceptors and donors (WTA $=0.03 \mathrm{eV}$ and $\mathrm{WTD}=0.06 \mathrm{eV}$ ). The mid-gap traps described by Gaussian distributions of donor-like states and acceptor-like states are:

$$
\begin{aligned}
& g_{G D}(E)=N G D \exp \left[-\left(\frac{E-E G D}{W G D}\right)^{2}\right] \\
& g_{G A}(E)=N G A \exp \left[-\left(\frac{E G A-E}{W G A}\right)^{2}\right]
\end{aligned}
$$

NGD and NGA are Gaussian maximum energy density of states in the doped layer $\left(\mathrm{NGD}=8 \mathrm{E}+17 \mathrm{~cm}^{-3}\right.$, $\mathrm{NGA}=5 \mathrm{E}+20 \mathrm{~cm}^{-3}$ ), while for the intrinsic layer the following applies: $\mathrm{NGD}=8 \mathrm{E}+15 \mathrm{~cm}^{-3}$ and $\mathrm{NGA}=5 \mathrm{E}+17 \mathrm{~cm}^{-3} . \mathrm{EGD}$ and EGA are the Gaussian peak energies, $\mathrm{EGD}=1.22 \mathrm{eV}$ and $\mathrm{EGA}=0.7 \mathrm{eV}$. The standard deviation for these functions is: $\mathrm{WGD}=\mathrm{WGA}=0.23 \mathrm{eV}$.

Capture cross-sections for the exponential "tail" distributions are: SIGTAE=1E-17, SIG$\mathrm{TAH}=1 \mathrm{E}-15$ for the acceptor traps, and SIG$\mathrm{TDE}=1 \mathrm{E}-15$, SIGTDH=1E-17 for the donor traps. Capture cross-section for acceptor-like and donor-like states of Gaussian levels are SIGGAE $=1 \mathrm{E}-15$, SIGGAH=1E-14, SIGGDE=1E-14 and SIGGDH=1E-15, respectively. These values are retained and are the same for c-Si, and also in the description of the interface a-Si/c-Si. The interface surface concentration of interface charge is $\mathrm{QF}=1 \mathrm{E}+10 \mathrm{~cm}^{-2}$, while the surface recombination velocity of electrons and holes are $\mathrm{S} . \mathrm{N}=\mathrm{S} . \mathrm{P}=1 \mathrm{E}+3 \mathrm{~cm} / \mathrm{s}$. Modeling was carried out for the life-time of carriers on the interface surface a$\mathrm{Si} / \mathrm{c}-\mathrm{Si}$, which is described in equations for the electrons and holes lifetimes:

$$
\begin{aligned}
& \frac{1}{\tau_{n}^{e f f}}=\frac{1}{\tau_{n}^{i}}+\frac{d_{i}}{A_{i}} S . N \\
& \frac{1}{\tau_{p}^{e f f}}=\frac{1}{\tau_{p}^{i}}+\frac{d_{i}}{A_{i}} \text { S.P }
\end{aligned}
$$

where $\tau^{\mathrm{i}}$ time specified for bulk of semiconductors, and $A_{i}$ and $D_{i}$ are the length and area of influence for each analyzed point.

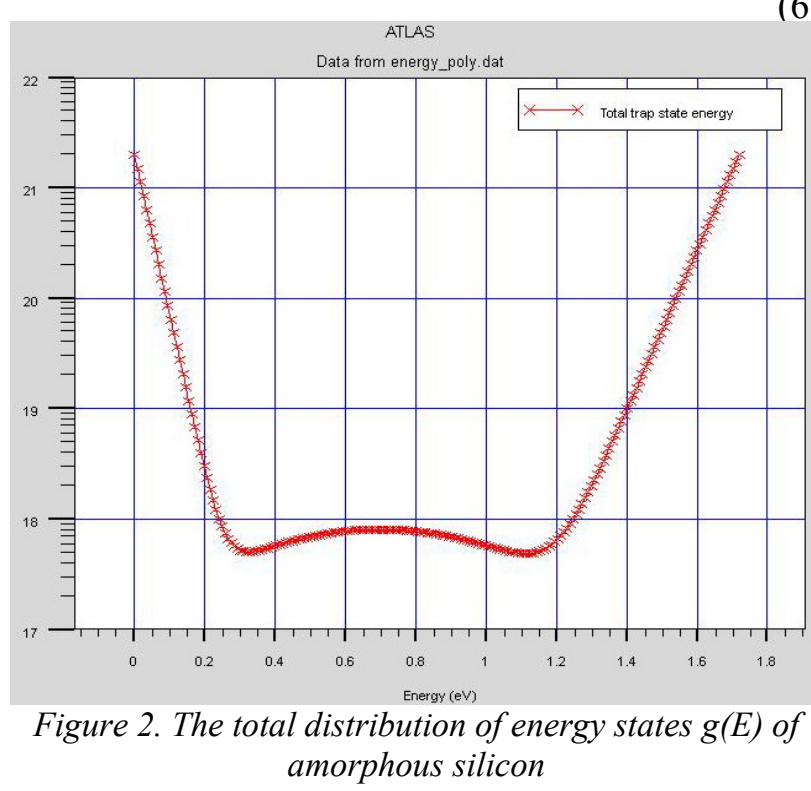

\section{SIMULATION RESULTS AND DISSCUSION}

The simulated HIT solar cell has two intrinsic amorphous layers on both sides of mono-crystal silicon, where both of them are $10 \mathrm{~nm}$ thick. The bulk itself is an n-type phosphor-doped, the concentration is from $3 \mathrm{E}+15 \mathrm{~cm}^{-3}$ to $1 \mathrm{E}+17 \mathrm{~cm}^{-3}$. The doped amorphous top layer is also a $10 \mathrm{~nm}$ thick, doped with boron, doping concentration is $3 \mathrm{E}+19 \mathrm{~cm}^{-3}$. The results showed that this concentration is a limit value for which the efficiency of solar cells enters saturation. The lower layer a-Si:H(n+) is doped with phosphorus, the concentration is $1 \mathrm{E}+19 \mathrm{~cm}^{-3}$. Anode electrode is a TCO-type, $80 \mathrm{~nm}$ thick, while the cathode is made of Al. During the simulation the possible reflection of light from the lower electrode is considered. For simulation under illumination the standard AM 1.5 normalized to $0.1 \mathrm{~W} / \mathrm{cm}^{2}$ or $100 \mathrm{mWcm}^{-2}$ (1sun) was used, the wavelength varies from $0.25 \mu \mathrm{m}$ to $2.4 \mu \mathrm{m}$. In this way the excitation of solar insulation for terrestrial systems is positioned. 
As already noted, the value of the workfunction for TCO electrodes affects the open circuit voltage $\mathrm{V}_{\mathrm{OC}}$ and thus the efficiency of solar cells. It is therefore important to perform the analysis of its influence. We take the values $4.9 \mathrm{eV}, 5.1 \mathrm{eV}, 5.3 \mathrm{eV}$ and $5.5 \mathrm{eV}$. The results of output simulated characteristics are shown in Figure 3, while Figure 4 shows the power that is distributed to the output contacts.

Therefore, for the values of WF less than $5.3 \mathrm{eV}$, the voltage $\mathrm{V}_{\mathrm{OC}}$ is significantly changeable and declining, while for larger values it saturates; the maximum value of $\mathrm{V}_{\mathrm{OC}}=0.6 \mathrm{~V}$ is obtained for the $\mathrm{WF}=5.5 \mathrm{eV}$. For example, when the simulation uses the level of doping $1 \mathrm{E}+16$ and $\mathrm{WF}=5.5 \mathrm{eV}$, we obtain the efficiency $\eta=22 \%$. It should be noted that the actual processes can make the TCO electrode with the indicated value of WF.

The next parameter that proved to be very important is the level of doping mono-crystalline silicon during the $\mathrm{CZ}$ process. The influence of this concentration is two-fold, at least taking into account the basic parameters. The first is the serial resistance reduction until the mobility of carriers is significantly reduced, increasing the $\mathrm{V}_{\mathrm{OC}}$, and the second is the influence on the width of the depletion region. As a side effect the relationship between the impurity concentration and interface traps could be observed. In Figure $5 \mathrm{~V}_{\mathrm{OC}}$ saturation is noticed, when the doping is greater than $1 \mathrm{E}+17 \mathrm{~cm}^{-3}$, and the decrease of $\mathrm{I}_{\mathrm{SC}}$ with increasing the substrate doping can also be observed (Figure 6). Figure 7 shows the dependence of output power, where the nominal voltage for a given level of doping can be read. In addition, in order to determine the coefficient of efficiency in \% it is only necessary to multiply the maximum value from the graphics to $10^{12}$ (take the absolute value). Besides the saturation of the $\mathrm{V}_{O C}$ there is also the saturation in the HIT solar cell efficiency $\eta$. Therefore, for optimum doping value can be $7 \mathrm{E}+16 \mathrm{~cm}^{-3}$, which gives $\mathrm{V}_{\mathrm{OC}}=0.64 \mathrm{~V}, \eta=23.6 \%$ and $\mathrm{FF}=83.48 \%$. With further doping, increased voltage slowly begins to decline, while the short circuit current starts to decrease significantly.

When it comes to optimizing the thickness of amorphous silicon layer, the simulations are carried out for the following thicknesses: $10 \mathrm{~nm}, 20 \mathrm{~nm}, 30$ $\mathrm{nm}, 40 \mathrm{~nm}$ and $50 \mathrm{~nm}$, with the same thickness for $\mathrm{p}+, \mathrm{n}+$ and intrinsic amorphous silicon. From the common graphic of all 5 structures (Figure 8), it is difficult to see the difference between I-V characteristics. The changing of current $\mathrm{I}_{\mathrm{SC}}$ is clearly evident in Figure 9 while the dependence of change in voltage $V_{O C}$ is shown in Figure 10. Thus, increasing the thickness of layers of amorphous silicon does not result in the substantial increase in $\mathrm{I}_{\mathrm{SC}}$ and $\mathrm{V}_{\mathrm{OC}}$. This suggests that the previously defined values for the $\mathrm{WF}$ and doping for mono-crystalline silicon can be kept, for the a-Si:H thickness as $10 \mathrm{~nm}$ for all layers, which would save both material and energy, which would ultimately impact reducing the price of HIT solar cells.

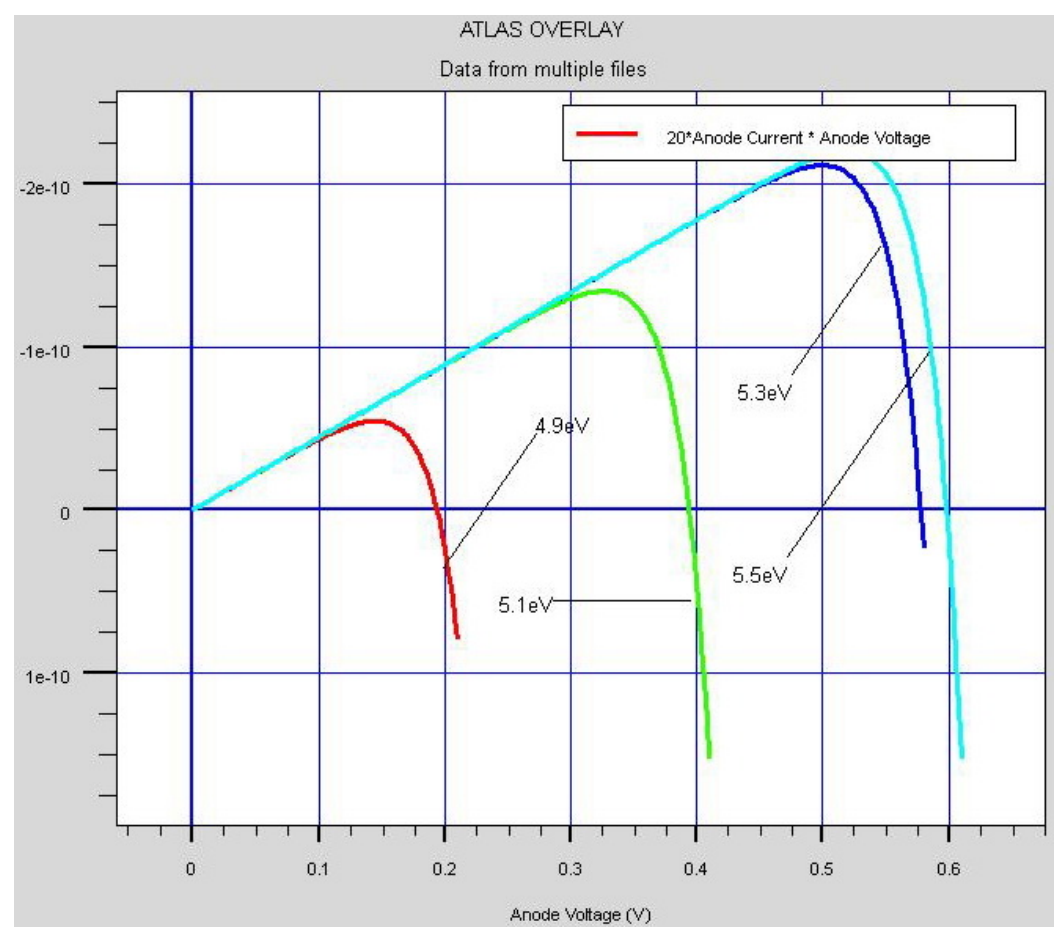

Figure 3. I-V characteristics of HIT solar cells for different values of the parameter WF 


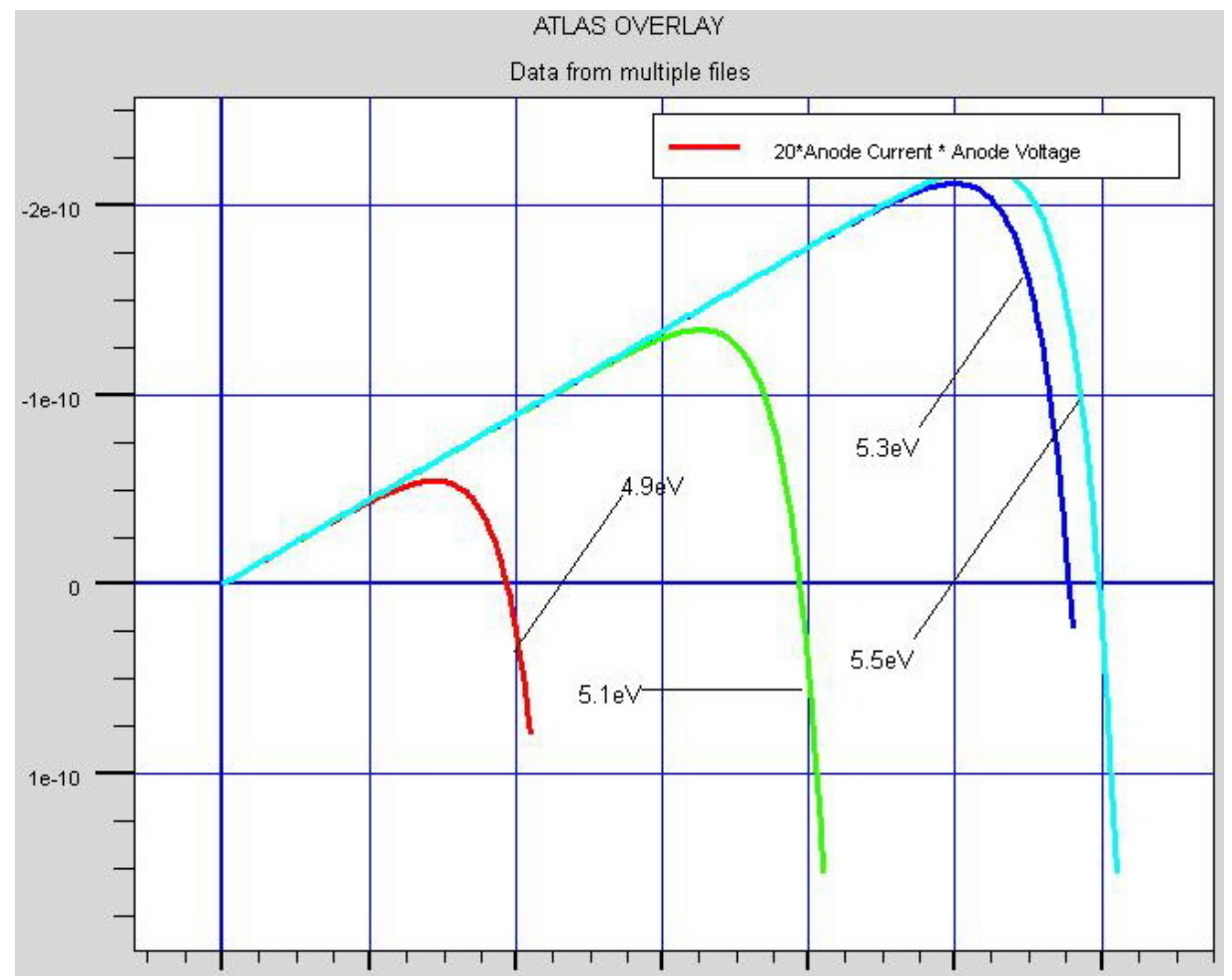

Figure 4. Output power per $\mu m^{2}$ for different values of the parameter WF

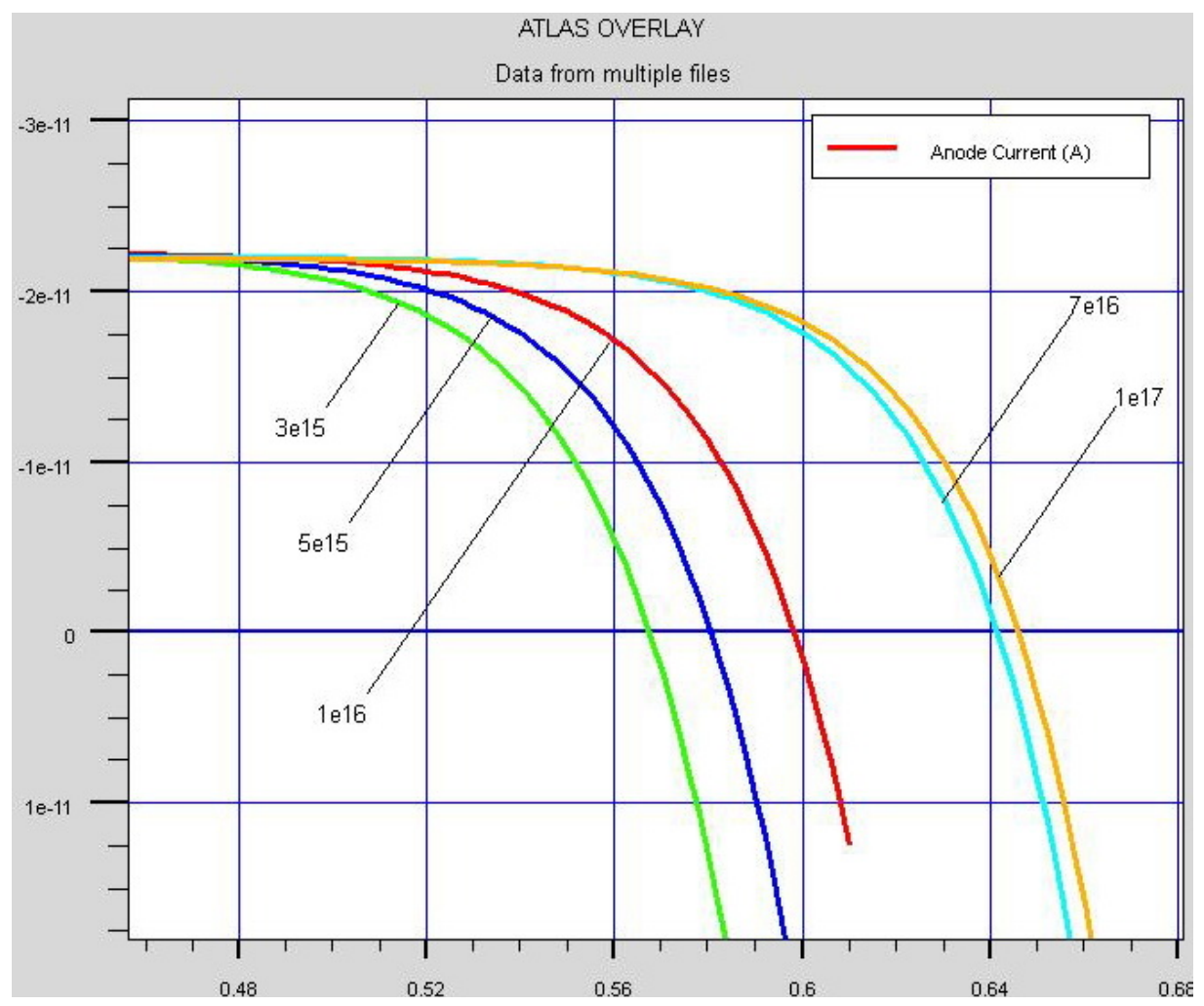

Figure 5. Dependence of $V_{\text {oc }}$ from doping of c-Si 


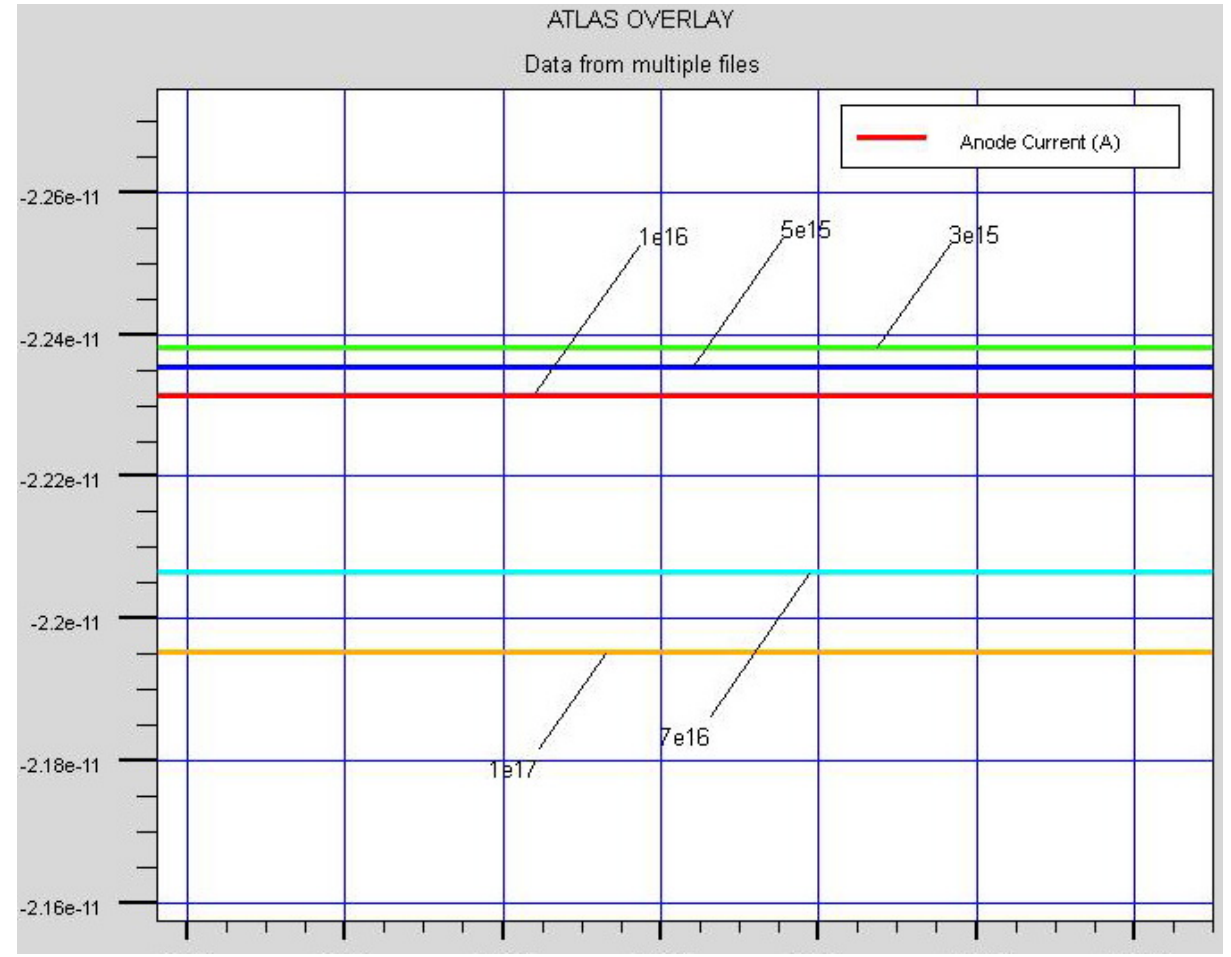

Figure 6. Dependence of $I_{s c}$ from doping of $\mathrm{c}-\mathrm{Si}$

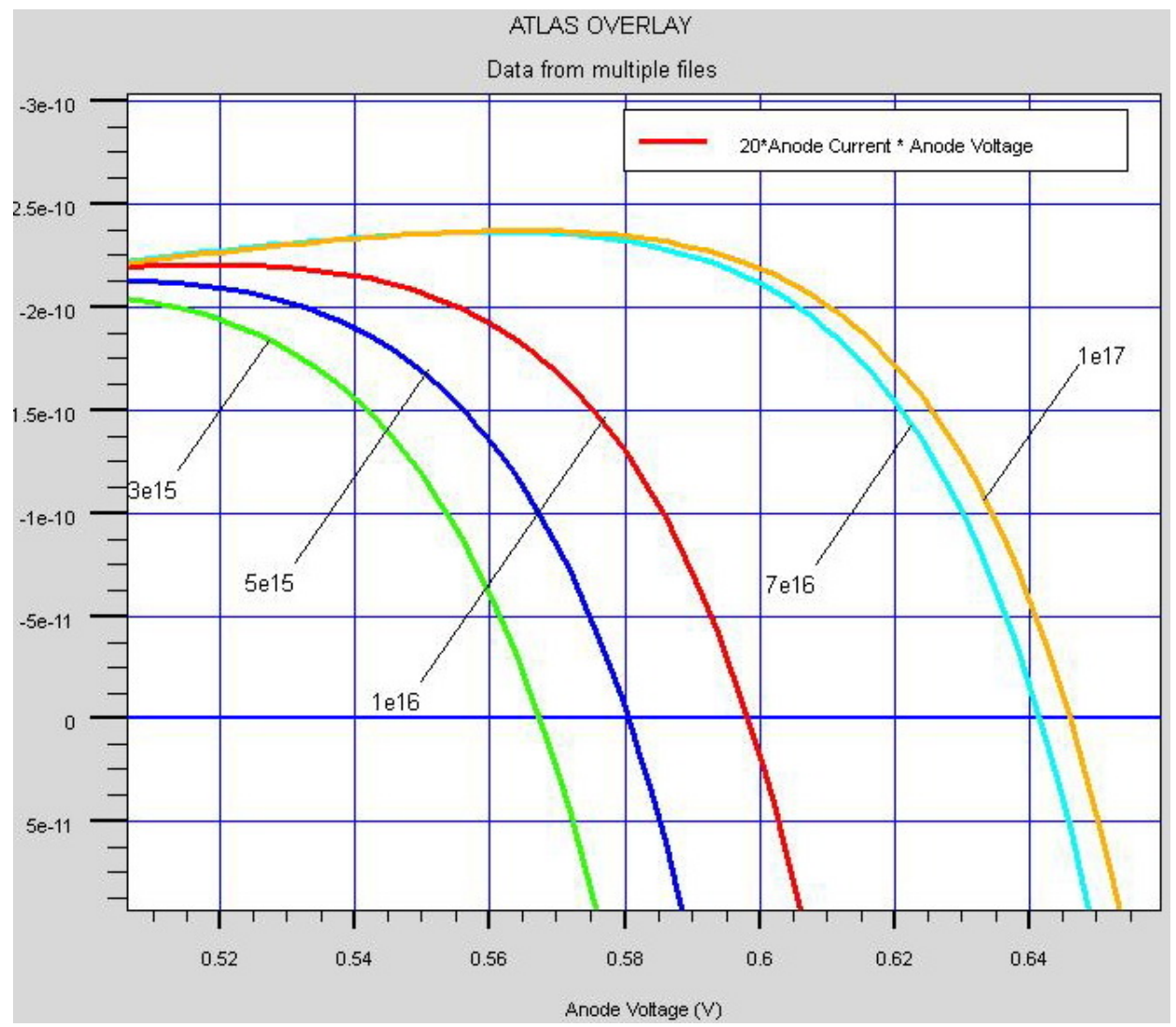

Figure 7. Dependence of $\mathrm{P}\left(\mathrm{W} / \mathrm{\mu m}^{2}\right)$ on doping of $\mathrm{c}-\mathrm{Si}$ 


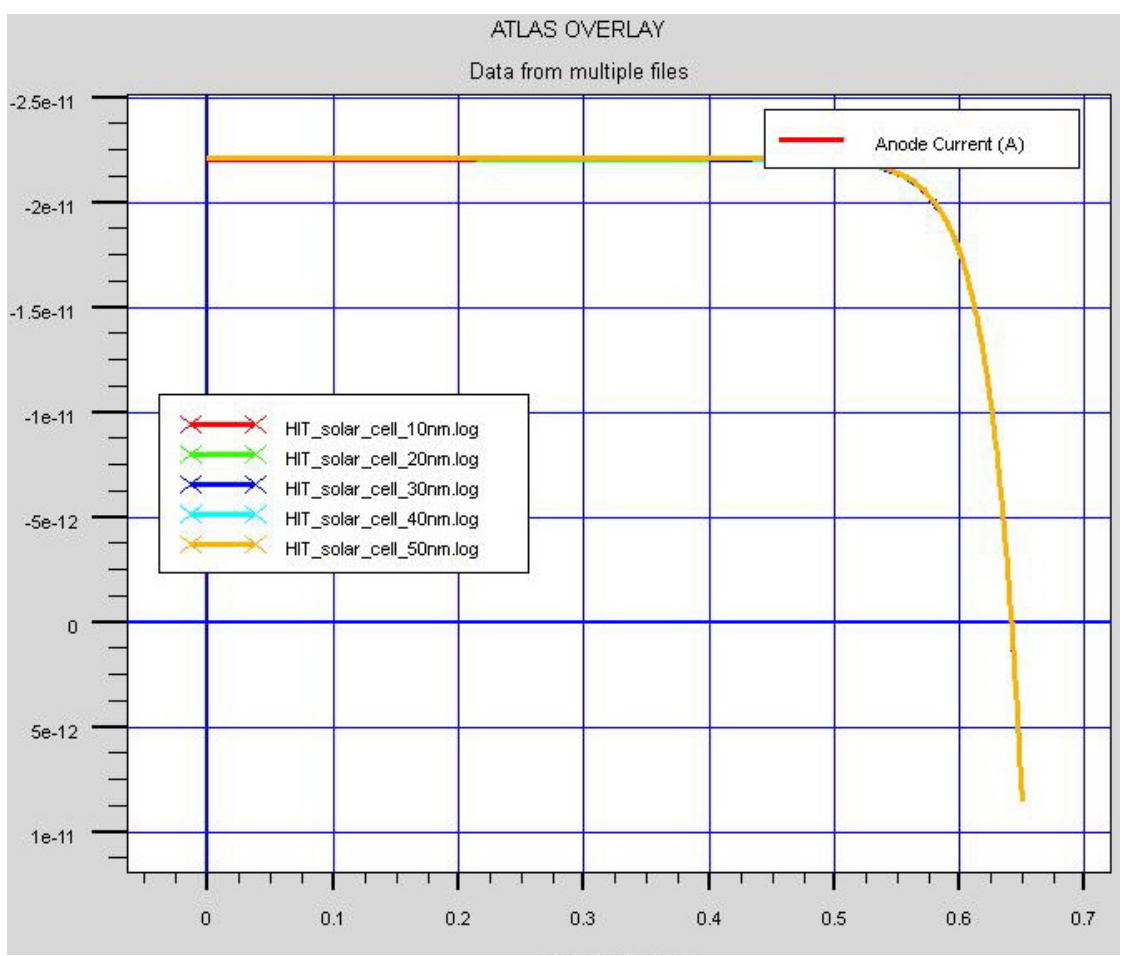

Figure 8. I-V characteristics of structures with variable thickness of a-Si

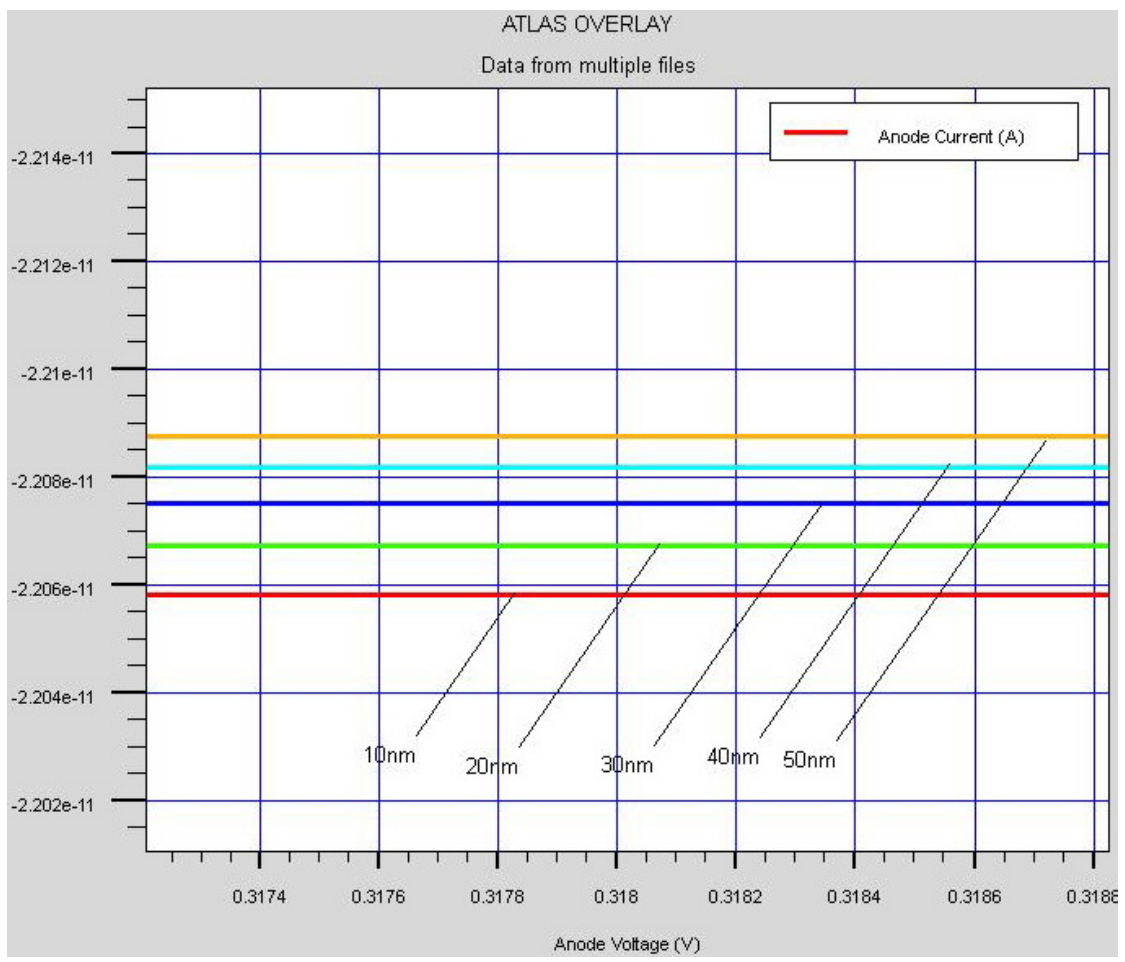

Figure 9. Dependence of $I_{S C}$ for structures with variable thickness of a-Si 


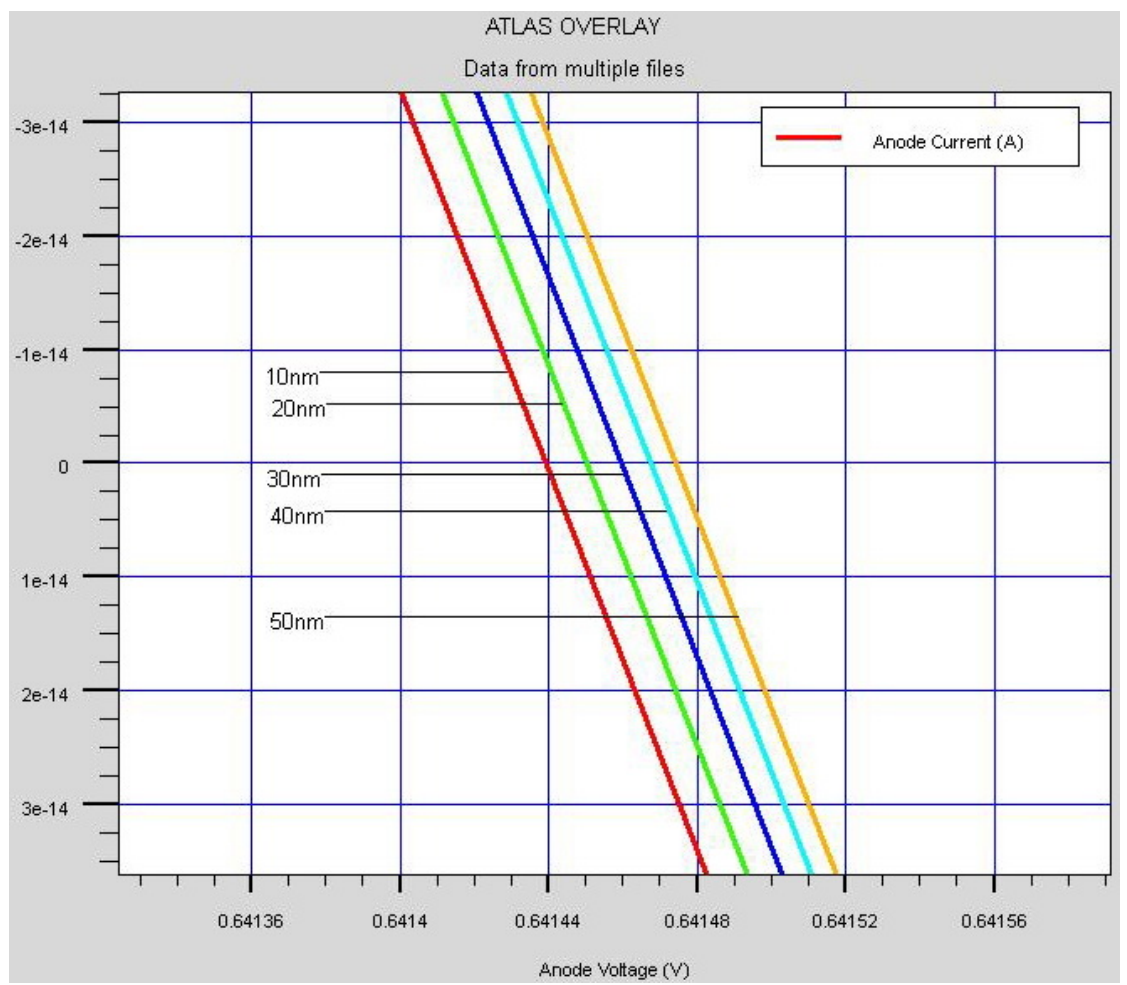

Figure 10. Dependence of $V_{O C}$ for structures with variable thickness of a-Si

\section{CONCLUSION}

This work presents the results of simulation and optimization of the technology flow, and electrical characteristics of HIT solar cells. For the simulation of technological processes of production, ATHENA software was used, while the electrical characteristics were simulated in ATLAS software. ATHENA and ATLAS programs are an integral part of the Silvaco TCAD (Technology Computer-Aided Design) software package. It is shown that the proper choices of physical model parameters are: mobility, generation and recombination, as well as defining the contacts, and the interface can successfully and accurately simulate the electrical characteristics of HIT solar cells. The structure with the best characteristics in terms of $V_{O C}$ and efficiency $\eta$ was obtained by optimizing the most important parameters of HIT structure: the level of doping and thickness of layers.

\section{REFERENCES}

[1] S. Taira, Y. Yoshimine, T. Baba, M. Taguchi, H. Kanno, T. Kinoshita, H. Sakata, E. Ma- ruyama, M. Tanaka, Our approaches for achieving HIT solar cells with more than 23\% efficiency, in: Proceedings of the 22nd European Photovoltaic Solar Energy Conference, Milan, Italy, 3-7 September 2007, 932-935.

[2] Y. Tsunomura, Y. Yoshimine, M. Taguchi, T. Kinoshita, H. Kanno, H. Sakata, E. Maruyama, M. Tanaka, 22\%-Efficiency HIT solar cell, SANYO Electric Co., sep. 2007.

[3] L. Zhao, C. L. Zhou, H. L. Li, H. W. Diao and W.J. Wang, Design optimization of bifacial HIT solar cells on p-type silicon substrates by simulation, Sol. Energy Mater. Sol. Cells 92 (2008), 673681.

[4] ATHENA User's Manual - Process Simulation Software, SILVACO, Santa Clara, USA 2009.

[5] ATLAS User's Manual - Device Simulation Software, SILVACO, Santa Clara, USA 2009.

[6] N. Hernández-Como, A. Morales-Acevedo, Simulation of hetero-junction silicon solar cells with AMPS-1D, Solar Energy Materials and Solar Cells 94, 1 (2010) 62-67. 
$\sin$

\section{СИМУЛАЦИЈА ЕЛЕКТРИЧНИХ КАРАКТЕРИСТИКА ХЕТЕРОСЛОЈНИХ СОЛАРНИХ ЋЕЛИЈА}

Сажетак: Соларни модули који се базирају на монокристалном и поликристалном силицијуму представљају скоро $90 \%$ укупног светског тржишта, пре свега због својих стабилних, робусних и поузданих карактеристика у поређењу са соларним ћелијама које се производе новим технологијама и које пре свега налазе примену у свемирским апликацијама. Из ових разлога се велика пажња посвећује побољшању њихових карактеристика, пре свега њихове ефикасности. Један од многобројних приступа је развој соларних ћелија које се производе на температурама нижим од $300^{\circ} \mathrm{C}$. Ове соларне ћелије су познате као ХИТ соларне ћелије - хетерослојне соларне ћелије са танким интринсичним слојем аморфног силицијума. У овом раду су карактеристике ХИТ соларних ћелија симулиране програмом Silvaco, при чему је њихова структура оптимизована са циљем да се добије њихова максимална ефикасност. Поред тога, описане су и модификације у процедури симулације које омогућавају симулацију ХИТ соларних ћелија, с обзиром на то да програм не узима у обзир високе концентрације међуповршинских густина стања, а које су карактеристичне за хетероспојеве аморфног и кристалног силицијума.

Кључне речи: соларне ћелије, хетероспој, аморфни силицијум, монокристални силицијум, симулација. 